\title{
PResidential Welcome AND AdDREsS
}

\author{
SÉAMUS MAC MATHÚNA \\ Seventh International Colloquium of Societas Celto-Slavica \\ Bangor, North Wales, 4-7 September 2014
}

Bore da ichi, a chroeso i Gymru ar gyfer Seithfed Gynhadledd Ryngwladol Cymdeithas Celto-Slavica. Rydym yn hapus iawn i fod yma yng Ngwynedd ac rwy'n mawr obeithio y byddwch yn mwynhau eich amser ym Mangor. Hoffwn ddiolch yn fawr iawn i Drefnydd a Chadeirydd y Gynhadledd, yr Athro Peredur Lynch, ac i'r Pwyllgor Trefnu am eu holl waith caled.

This year, in July, Societas Celto-Slavica celebrated its tenth anniversary. It has been a good ten years, busy and full of many highlights. We have held academic conferences in a number of different Slavic countries (Moscow and St Petersburg in the Russian Federation; Łódź in Poland; Dubrovnik in Croatia; Př́bram in the Czech Republic); one in Northern Ireland (the first conference in Coleraine); and now, the Seventh Colloquium here in Bangor, Gwynedd. All the conferences have been a joy: very pleasant occasions in some wonderful, even exotic locations, with much good humour, comraderie and impressive scholarship, all of which contributed greatly to their success. It is pleasing for Celto-Slavica to be in Wales on the occasion of our tenth anniversary, the country with probably the strongest Celtic language today. It is particularly pleasing to be here in Bangor, which has a long and illustrious tradition of Welsh and Celtic scholarship. We thank Professor Peredur Lynch, the Conference Organiser, and the members of the Organising Committee, for their hard work and dedication in preparing such a fine and varied programme of lectures and events which, I am sure, will be most enjoyable and informative. We are very grateful to you.

Perhaps it is worth saying a few words at this time about the state of the Societas and the work which may lie ahead in the years to come. I should say at the outset that we are blessed in having many young scholars of great ability who come both from the Slavic and Celtic countries and from many other countries; trained by excellent dedicated teachers, they present papers regularly at our conferences. This bodes well 
for the future and I would encourage these young scholars to take an active part in promoting and developing the Society so that it will continue to grow and develop as an academic body capable of making an important contribution to Celtic Studies and the relationship between Slavic and Celtic languages and cultures.

At the inaugural conference in Coleraine in 2005, Professor Hildegard Tristram, who unfortunately cannot be with us here in Bangor, pointed out that, despite the fact that some work had been carried out on various aspects of relations between Celtic and Slavic, no coherent account of connections and exchanges between these cultures, both ancient and modern, had yet been written. She hoped that Societas CeltoSlavica would "lay the foundation for a future general conspectus of the linguistic, literary and cultural topics of shared interest between these two important European cultural domains" (Tristram 2006: 254-5). Over the past ten years our conferences and seminars have addressed a range of comparanda and parallels between the two traditions covering elements relating to these various topics. Many of the relevant papers have been published in the Societas's series Studia Celto-Slavica and we should hopefully be in a position before too long to embark on the general conspectus referred to by Professor Tristram in her paper.

One recent development which will, I believe, contribute to meeting this objective is the international research network involving a number of scholars and institutions under the direction of Professor Jadranka Gvozdanović of the University of Heidelberg on the question of language, cultural heritage and integrating identities in Europe from the perspective of Slavic and Celtic cultures. This will, we hope, lead to a deeper understanding of European culture in general. It is also our hope that Professor Gvozdanović will chair the Organising Committee of the next conference of the Society at the University of Heidelberg.

Similarly, the longstanding international research network spearheaded by Professors Jacqueline Borsje and Tatyana Mikhailova on the Power of Words in Traditional European Societies, with a major focus on European peripheries, has already deepened our understanding and knowledge of the literary and religious history of European culture. These words of power include curses, blessings, spells, charms, incantations and prayers. Yet another project on the subject of Maritime Memorates, under the directorship of Dr Maxim Fomin and myself and funded by the UK's Arts and Humanities Research Council, has hitherto concentrated primarily on materials in Irish, Scottish Gaelic and English, but will also seek in the future to encompass the other Celtic languages and also the Slavic and Scandinavian traditions (Fomin and Mac Mathúna 2016). This 
should contribute to a greater knowledge of an important subject area in the European folk tradition.

Other projects which will contribute to the general conspectus of the two cultures are the History of Celtic Scholarship in the Slavic Countries, which was begun many years ago and is still ongoing (Mac Mathúna 2006); and monographs and histories dealing with contacts over the centuries between Celts and Slavs as reflected in language, archaeology, literature, folklore and mythology, including, for example, comparative studies covering such matters as linguistic aspect.

Finally, thanks again to Professor Lynch and the Organising Committee. I wish conference well and look forward to a productive and enjoyable time here in Bangor.

Ulster University

\section{References}

Fomin, M., and Mac Mathúna, S., 2016, Stories of the Sea: Maritime Memorates of Ireland and Scotland, Berlin: Curach Bhán Publications.

Mac Mathúna, S., 2006, 'The History of Celtic Scholarship in Russia and the Soviet Union', in: Mac Mathúna, S., \& Fomin, M., eds., Parallels between Celtic and Slavic. Proceedings of the First International Colloquium on Links and Parallels between Celtic and Slavic Traditions. Studia Celto-Slavica 1, Coleraine: TSO Publishers, 3-42.

Tristram, H. L. C., 2006, 'Concluding Remarks: What's in CeltoSlavica?', in: Mac Mathúna, S., \& Fomin, M., eds., Parallels between Celtic and Slavic. Proceedings of the First International Colloquium on Links and Parallels between Celtic and Slavic Traditions. Studia CeltoSlavica 1, Coleraine: TSO Publishers, 253-65. 